Article available at nttp://Www.parasite-journal.org or nttp://dx.dol.org/10.1051/parasite/1999063249

\title{
Cestode communities in nON-Breeding populations OF FOUR GREBE SPECIES (AVES: PODICIPEDIDAE) from the Bulgarian Black Sea coast
}

\author{
VASILEVA G.P.* \& GEORGIEV B.B.*
}

\section{Summary :}

Cestode communities in Podiceps cristatus, P. grisegena, P. nigricollis and Tachybaptus ruficollis during their migrations and overwintering are studied at the Bulgarian Black Sea coast. The infracommunities exhibit high richness, abundance and dominance, and low diversity and similarity. The component communities have a similar taxonomic structure at the levels higher than species, a small number of core species and a high portion of grebe specialists in the richness and abundance. The comparison with cestode communities in grebes from Canada (Stock \& Holmes, 1987) reveals several differences and similarities. The higher richness and abundance of the infracommunities in Canada are explained by the constant conditions of breeding habitats enhancing higher transmission rates. At the component community level, there is a significant difference between the two species lists. The degree of parasite exchange among the grebe species in Bulgaria is lower. Several characters of cestode component communities in grebes do not depend on either historical factors or different habitats. These are the similar patterns of the taxonomic structure at the levels higher than species, almost the same list of generalists, the participation of specialists of anatids, and the leading role of grebe specialists in the structure.

KEY WORDS : parasite ecology, communities, cestodes, Podicipedidae, Bulgaria.
Résumé : LES COMMUNAUTÉS DE CESTODES DANS LES POPULATIONS NON REPRODUCTRICES DE QUATRE ESPĖCES DE GRÈBE (AVES: Podicipedidae) DE LA CÔTE BULGare DE LA MER NoIRE

Cette étude porte sur les communautés de cestodes de Podiceps cristatus, P. grisegena, P. nigricollis, Tachybaptus ruficollis pendant leurs migrations et leur hibernage sur la côte bulgare de la Mer Noire. Les infracommunautés montrent une grande richesse, abondance et dominance, une faible diversité et une faible similarité. Les xénocommunautés ont une structure taxonomique semblable pour les niveaux supérieurs aux espèces, un petit nombre d'espèces cores et une grande proportion de spécialistes des grèbes en richesse et en abondance. La comparaison avec les communautés de cestodes des grèbes du Canada (Stock \& Holmes, 1987) révèle plusieurs différences et similitudes. Les plus grandes richesse et abondance des infracommunautés au Canada sont expliquées par la constance des conditions dans les habitats de reproduction qui favorise un taux de transmission plus élevé. Au niveau de la xénocommunauté, il y a une différence significative entre les deux listes d' espèces. Le degré d'échange de parasites est plus bas parmi les espèces de grèbes de Bulgarie. Plusieurs caractères des xénocommunautés de cestodes chez les grèbes ne dépendent ni des facteurs historiques ni des différences d'habitat. Ceux-ci sont les patrons similaires des structures taxonomiques de niveaux supérieurs aux espèces, la liste pratiquement identique des généralistes, la participation de spécialistes des anatides et le rôle majeur des spécialistes des grèbes dans la structure.

MOTS CLÉS : écologie parasitaire, communautés, cestodes, Podicipedidae, Bulgarie.

occurrence, was identified. Stock \& Holmes (1987) indicated that the level of the host specificity and the food habits of the host are important determinants of the structure of helminth communities in grebes.

There are numerous faunistic and taxonomic studies on cestode parasites from grebes in the Palaearctic (reviewed by Ryzhikov et al., 1985). They show that this specialised group of aquatic birds supports a species-rich cestode fauna. However, no studies on cestode communities in Palaearctic grebes have been carried out. The aim of the present article is to describe the cestode communities in Palaearctic grebes and to identify the main factors determining their structure. Since the breeding populations are highly protected in Bulgaria, the samples were collected from migrating and overwintering birds along the Bulgarian Black Sea coast.

\footnotetext{
* Central Laboratory of General Ecology, Bulgarian Academy of Sciences, 2 Gagarin Street, 1113 Sofia, Bulgaria.

Correspondence: Dr Boyko B. Georgiev.

Tel.: (+3592) 717 195, 705108 - Fax: (+3592) 705498

E-mail: bbg@ecolab.bas.bg
} 


\section{MATERIALS AND METHODS}

A total of 44 birds belonging to four grebe species were collected under a license of the Ministry of Environment of the Republic of Bulgaria during 1983-1994. These were 12 Podiceps cristatus (L.), 21 P. nigricollis Brehm, four P. grisegena (Boddaert) and seven Tachybaptus ruficollis (Pallas). The birds were captured from three localities along the Bulgarian Black Sea coast (Lake Durankulak, Lake Pomorie and Burgas) in January, March-April and September-October. Representative samples of cestodes were isolated alive from the intestines, relaxed in tap water, fixed in $10 \%$ formalin and preserved in $70 \%$ ethanol. Subsequently, they were stained in iron acetocarmine, dehydrated in an ascending alcohol series, cleared in eugenol and mounted in Canada balsam, or mounted in Berlese's medium, for the purposes of adequate morphological and taxonomic studies. All remaining gut contents including cestodes were fixed in $4 \%$ formalin for subsequent examination. All the cestode specimens were identified and counted.

The cestode identification was based on the following works: Baer (1954), Dubinina (1966), Temirova \& Skryabin (1978), Ryzhikov \& Tolkacheva (1981), Ryzhikov et al. (1985), Gulyaev $(1990,1992)$ and Vasileva et al. (1996a, b, 1998, 1999a-c).

The terminology used in the description of helminth communities follows Bush et al. (1997).

For consistency of the comparisons, the prevalence criteria of $40 \%$ and $70 \%$ were adopted for the identification of satellite, secondary and core species (as applied by Stock \& Holmes, 1987). The following parameters of community structure were calculated at the infracommunity level: the mean number of cestode species and individuals, the mean Brillouin's Index (HB), the mean index PIE' and the mean BergerParker Dominance Index (d) (see Magurran, 1988; Krebs, 1989; Baev \& Penev, 1995). The participation of the specific parasites of the Podicipedidae (= grebe specialists) in the infracommunity abundance is characterised by the modified Berger-Parker Dominance Index $\left(d^{\prime}=N_{\text {spec }} / N\right.$, where $N_{\text {spec }}$ is the total number of individuals of grebe specialists, and $\mathrm{N}$ is the total number of cestode individuals in the sample), as applied by Kostadinova (1993) for trematode communities. The similarity was measured using Jaccard Coefficient (SJ) for qualitative data and the Percent Similarity Index (PS) for quantitative data (Krebs, 1989). Medians, mean values and SD of the similarity of each infracommunity sample sets (corresponding to each of the four component communities studied) was calculated on the basis of the comparisons between all possible pairs of infracommunities within each grebe species.
The random distribution of cestode species in each of the four infracommunity sample sets was tested by the Index of Dispersion Test (IDT) (Krebs, 1989).

The prevalence and mean intensity data presented by Stock \& Holmes (1987) have been used to calculate: 1) the total number of individuals of each cestode species in a certain grebe species ( $=$ prevalence $\times$ number of examined birds $\times$ mean intensity); 2 ) mean number of cestode species in a certain grebe species (= sum of prevalences/100) (see Holmes, 1990). The former has been used to calculate the mean number of individuals in each host species as well as the parameters of diversity (HB, PIE', d) and similarity (SJ and PS) at the component community level.

All diversity and similarity measures were calculated by the program BIODIV (Baev \& Penev, 1995). Standard non parametric Kruskal-Wallis (K-W) and MannWhitney (M-W) tests were used for hypothesis testing (Sokal \& Rohlf, 1981).

\section{RESULTS}

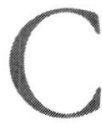

estode communities of grebes examined along the Bulgarian Black Sea coast were characterised by a high species richness and abundance. Out of 44 birds, 43 were infected with cestodes and only one specimen of P. cristatus was uninfected. Infected individual birds harboured one to six cestode species. A total of 27 cestode species was found (Table I). The parameters of the cestode communities are given in Table II

\section{Cestode component communities}

Species richness and abundance

Although the cestode species diversity was high (Table I), the four host species had similar component community taxonomic structure at the level of the family. The families Hymenolepididae and Amabiliidae exhibited the highest species richness and abundance. The majority of the recorded species belonging to these families were grebe specialists (see Spasskaya, 1966; Ryzhikov \& Tolkacheva, 1981; Ryzhikov et al., 1985; Galkin, 1986). The remaining species, belonging to the families Diphyllobothriidae, Tetrabothriidae and Dilepididae, showed considerably lower richness and abundance.

The component cestode community in $P$. nigricollis demonstrated the highest species richness and abundance. $43 \%$ of individual $P$. nigricollis had more than four cestode species and $43 \%$ had infection of more than 300 tapeworms. The family Hymenolepididae had the highest species richness (53.3\%); among them, Confluaria furcifera and C. podicipina were the most frequent and abundant (Table I). Amabiliids had 


\begin{tabular}{|c|c|c|c|c|c|c|c|c|c|c|c|c|c|c|c|c|}
\hline \multirow[b]{2}{*}{ Taxa } & \multirow{2}{*}{$\begin{array}{l}\text { Speci- } \\
\text { ficity }\end{array}$} & \multicolumn{4}{|c|}{ Podiceps cristatus } & \multicolumn{4}{|c|}{ Podiceps nigricollis } & \multicolumn{4}{|c|}{ Podiceps grisegena } & \multicolumn{3}{|c|}{ Tachybaptus ruficollis } \\
\hline & & $\mathrm{P} \%$ & MI & MA & S & $\mathrm{P} \%$ & MI & MA & S & $\mathrm{P} \%$ & MI & MA & S & P\% & $\mathrm{Ml}$ & MA \\
\hline
\end{tabular}

\section{Diphyllobothriidae}

Ligula intestinalis (L., 1758)

\section{Tetrabothriidae}

Tetrabothrius macrocephalus (Rud., 1810)

\section{Dilepididae}

Paricterotaenia porosa (Rud., 1810)

\section{Amabiliidae}

Ryjikovilepis dubininae (Ryzhikov \&

Tolkacheva, 1981)

Schistotaenia macrorhyncha (?) (Rud., 1810)

S. rufi (Sulgostowska \& Korpaczewska, 1969)

Schistotaenia sp.

Tatria acanthorbyncha (Wedl, 1855)

T. biremis Kowalewski, 1904

T. biuncinata (Joyeux \& Baer, 1943)

T. minor Korpaczewska \& Sulgostowska, 1974

T. mircia (Gulyaev, 1990)

T. octacantha Rees, 1973

T. pilatus (Borgarenko \& Gulyaev, 1991)

Tatria sp.

\section{Hymenolepididae}

Confluaria capillaris (Rud., 1810)

C. furcifera (Krabbe, 1869)

C. multistriata (Rud., 1810)

C. podicipina (Szymanski, 1905)

C. pseudofurcifera Vasileva et al., 1999

Confluaria sp.

Dollfusilepis boploporus (Dollfus, 1951)

Fimbriarioides sp.

Mackoja podirufi (Macko, 1962)

Microsomacanthus sp. 1

Microsomacanthus sp. 2

Pararetinometra lateralacantha Stock \&

Holmes, 1981

\begin{tabular}{|c|c|c|c|c|c|c|c|c|c|c|c|c|c|c|c|c|}
\hline G & 16.7 & 3.0 & 0.5 & Sat & - & - & - & - & - & - & - & - & - & - & - & - \\
\hline G & 33.3 & 3.5 & 1.2 & Sat & 4.8 & 163.0 & 7.8 & Sat & 50.0 & 76.0 & 38.0 & $\mathrm{Sec}$ & - & - & - & - \\
\hline A & - & - & - & - & 14.3 & 23.3 & 3.3 & Sat & - & - & - & - & - & - & - & - \\
\hline $\mathrm{X}$ & - & - & - & - & 28.6 & 11.2 & 3.2 & Sat & - & - & - & - & - & - & - & - \\
\hline$X$ & - & - & - & - & 4.8 & 1.0 & 0.05 & Sat & - & - & - & - & 14.3 & 1.0 & 0.1 & Sat \\
\hline $\mathrm{X}$ & - & - & - & - & - & - & - & - & - & - & - & - & 14.3 & 1.0 & 0.1 & Sat \\
\hline X & 8.3 & 1.0 & 0.1 & Sat & - & - & - & - & - & - & - & - & - & - & - & - \\
\hline$X$ & - & - & - & - & - & - & - & - & - & - & - & - & 71.4 & 10.6 & 7.6 & $\mathrm{C}$ \\
\hline $\mathrm{X}$ & 16.7 & 207.5 & 34.6 & Sat & 76.2 & 173.3 & 132.0 & C & 75.0 & 114.3 & 85.8 & C & 28.6 & 7.5 & 2.1 & Sat \\
\hline X & - & - & - & - & - & - & - & - & - & - & - & - & 14.3 & 259.0 & 37.0 & Sat \\
\hline X & 8.3 & 11.0 & 0.9 & Sat & 33.3 & 744.6 & 248.2 & Sat & - & - & - & - & - & - & - & - \\
\hline $\mathrm{X}$ & 33.3 & 53.5 & 17.8 & Sat & 14.3 & 165.7 & 23.7 & Sat & 25.0 & 4.0 & 1.0 & Sat & - & - & - & - \\
\hline X & - & - & - & - & - & - & - & - & - & - & - & - & 14.3 & 1.0 & 0.1 & Sat \\
\hline X & - & - & - & - & - & - & - & - & - & - & - & - & 28.6 & 1.5 & 0.4 & Sat \\
\hline $\mathrm{X}$ & - & - & - & - & - & - & - & - & - & - & - & - & 14.3 & 4.0 & 0.6 & Sat \\
\hline $\mathrm{X}$ & 8.3 & 105.0 & 8.8 & Sat & - & - & - & - & 75.0 & 32.7 & 24.5 & $\mathrm{C}$ & - & - & - & - \\
\hline $\mathrm{X}$ & - & - & - & - & 66.7 & 27.4 & 18.2 & $\mathrm{Sec}$ & 75.0 & 175.0 & 131.3 & $\mathrm{C}$ & 14.3 & 3.0 & 0.4 & Sat \\
\hline$X$ & - & - & - & - & 4.8 & 1.0 & 0.05 & Sat & - & - & - & - & 42.9 & 39.7 & 17.0 & $\mathrm{Sec}$ \\
\hline $\mathrm{X}$ & - & - & - & - & 47.6 & 68.2 & 32.5 & $\mathrm{Sec}$ & - & - & - & - & 28.6 & 33.0 & 9.4 & Sat \\
\hline $\mathrm{X}$ & 50.0 & 8.2 & 4.1 & $\mathrm{Sec}$ & - & - & - & - & - & - & - & - & - & - & - & - \\
\hline $\mathrm{X}$ & - & - & - & - & 19.0 & 15.5 & 3.0 & Sat & - & - & - & - & 14.3 & 1.0 & 0.1 & Sat \\
\hline X & 33.3 & 2.8 & 0.9 & Sat & - & - & - & - & - & - & - & - & - & - & - & - \\
\hline A & - & - & - & - & - & - & - & - & 25.0 & 4.0 & 1.0 & Sat & - & - & - & - \\
\hline $\mathrm{X}$ & - & - & - & - & 4.8 & 1.0 & 0.05 & Sat & - & - & - & - & 42.9 & 19.7 & 8.4 & Sec \\
\hline A & - & - & - & - & 4.8 & 2.0 & 0.1 & Sat & - & - & - & - & - & - & - & - \\
\hline A & - & - & - & - & 4.8 & 14.0 & 0.7 & Sat & - & - & - & - & - & - & - & - \\
\hline $\mathrm{X}$ & - & - & - & - & 4.8 & 25.0 & 1.2 & Sat & - & - & - & - & - & - & - & - \\
\hline
\end{tabular}

Abbreviations: G: generalists; X: grebe specialist; A: accidental species (specialists of other hosts group); C: core species; Sec: secondary species; Sat: satellite species.

Table I. - Prevalences (P\%), mean intensities (MI), mean abundances (MA) and status (S) of cestode species found in four grebe species from Bulgarian Black Sea coast. 
the major portion of the total component community abundance $(85.9 \%)$ due to the high values of prevalence and/or mean abundance of Tatria spp. and Ryjikovilepis dubininae.

Tachybaptus ruficollis had also a species-rich and abundant component community. Only amabiliids and hymenolepidids were found in this host. The former had the highest species richness and abundance. In addition to the common grebe specialist Tatria biremis, the component community of $T$. ruficollis comprised six other amabiliids recovered only in this host. Among hymenolepidids, Confluaria multistriata, Mackoja podirufi and $C$. podicipina showed the highest values of prevalence and mean abundance (Table I).

The component cestode community in $P$. cristatus comprised nine species. The Amabiliidae prevailed in this host in both richness and abundance (44.4\% and $77.6 \%$, respectively). The species with the highest pre-

\begin{tabular}{|c|c|c|c|c|c|c|c|c|}
\hline \multirow[b]{2}{*}{ Locality } & \multicolumn{4}{|c|}{ Alberta (Canada) } & \multicolumn{4}{|c|}{ Black Sea Coast (Bulgaria) } \\
\hline & A0 & PG & $\mathrm{PN}$ & $\mathrm{PA}$ & $\mathrm{PC}$ & $\mathrm{PN}$ & PG & TR \\
\hline Birds examined & 20 & 33 & 31 & 7 & 12 & 21 & 4 & 7 \\
\hline Cestode species number & 10 & 13 & 19 & 11 & 9 & 15 & 6 & 13 \\
\hline \multicolumn{9}{|l|}{ Infracommunities } \\
\hline $\begin{array}{l}\text { Mean number of species } \\
\text { per bird }\end{array}$ & 3.9 & 6.2 & 7.6 & 4.7 & 2.1 & 3.3 & 3.3 & 3.4 \\
\hline SD & - & - & - & - & 1.2 & 1.5 & 1.7 & 1.7 \\
\hline Median & - & - & - & - & 2.0 & 3.0 & 3.5 & 3.0 \\
\hline Range & - & - & - & - & $0-4$ & $1-6$ & $1-5$ & $1-6$ \\
\hline $\begin{array}{l}\text { Mean number of individuals } \\
\text { per bird }\end{array}$ & 336.3 & 1475.5 & 6135.5 & 1858.4 & 68.8 & 473.9 & 281.5 & 83.6 \\
\hline $\mathrm{SD}$ & - & - & - & - & 117.3 & 501.6 & 426.8 & 100.2 \\
\hline Median & - & - & - & - & 7.5 & 257.0 & 104.5 & 35.0 \\
\hline Range & - & - & - & - & $0-368$ & $19-1865$ & $4-913$ & $5-294$ \\
\hline \multicolumn{9}{|l|}{ Brillouin's Index (HB) } \\
\hline Mean & - & - & - & - & 0.339 & 0.527 & 0.695 & 0.497 \\
\hline $\mathrm{SD}$ & - & - & - & - & 0.37 & 0.44 & 0.53 & 0.25 \\
\hline Median & - & - & - & - & 0.357 & 0.423 & 0.760 & 0.648 \\
\hline \multicolumn{9}{|l|}{ Diversity Index (PIE') } \\
\hline Mean & - & - & - & - & 0.261 & 0.299 & 0.403 & 0.320 \\
\hline \multicolumn{9}{|l|}{ Berger-Parker Index (d) } \\
\hline Mean & - & - & - & - & 0.726 & 0.790 & 0.690 & 0.785 \\
\hline SD & - & - & - & - & 0.29 & 0.19 & 0.27 & 0.13 \\
\hline Median & - & - & - & - & 0.784 & 0.860 & 0.685 & 0.762 \\
\hline \multicolumn{9}{|l|}{ Jaccard similarity (SJ) } \\
\hline Mean & - & - & - & - & 0.165 & 0.289 & 0.358 & 0.172 \\
\hline SD & - & - & - & - & 0.211 & 0.202 & 0.398 & 0.153 \\
\hline Median & - & - & - & - & 0.000 & 0.250 & 0.300 & 0.167 \\
\hline \multicolumn{9}{|l|}{ Percent similarity } \\
\hline Mean & - & - & - & - & 0.113 & 0.355 & 0.197 & 0.169 \\
\hline SD & - & - & - & - & 0.18 & 0.32 & 0.24 & 0.23 \\
\hline Median & - & - & - & - & 0.000 & 0.290 & 0.095 & 0.048 \\
\hline \multicolumn{9}{|l|}{$\begin{array}{l}\text { Component communities } \\
\text { (estimated on summed data) }\end{array}$} \\
\hline Brillouin's Index (HB) & 0.470 & 1.190 & 1.610 & 0.462 & 1.330 & 1.350 & 1.230 & 1.570 \\
\hline Diversity Index (PIE') & 0.205 & 0.579 & 0.755 & 0.231 & 0.660 & 0.639 & 0.664 & 0.731 \\
\hline Berger-Parker Index (d) & 0.888 & 0.603 & 0.342 & 0.870 & 0.502 & 0.524 & 0.466 & 0.443 \\
\hline \multicolumn{9}{|l|}{ Dominant structure } \\
\hline Core species number & 3 & 6 & 6 & 2 & 0 & 1 & 3 & 1 \\
\hline Secondary species number & 0 & 0 & 2 & 4 & 1 & 2 & 1 & 2 \\
\hline Satellite species number & 7 & 7 & 11 & 5 & 8 & 12 & 2 & 10 \\
\hline
\end{tabular}

Abbreviations: AO: Aechmophorus occidentalis; PG: Podiceps grisegena; PN: P. nigricollis; PA: P. auritus; PC: P. cristatus; TR: Tachybaptus ruficollis.

Table II. - Parameters of the cestode communities in grebes from Alberta (from Stock \& Holmes, 1987, or based on their data after recalculation) and Bulgaria (present study). 
valence and abundance were Tatria mircia and T. biremis. In the second position of species richness and abundance was the family Hymenolepididae. Two of the three hymenolepidids found in P. cristatus (Confluaria pseudofurcifera and Dollfusilepis hoploporus) occurred in this grebe only. The other two cestode families were represented each by a single species.

$P$. grisegena had the lowest total species richness of the component community. The cestode species belonged to three families. Among them, the Hymenolepididae had the highest richness (50\%) and abundance $(55.7 \%)$, the latter due to the high prevalence and abundance of $C$. capillaris and $C$. furcifera.

\section{Similarity}

Out of 27 cestode species recovered, only one, Tatria biremis, was shared by the four grebe species. The qualitative similarity between the four component communities was low to moderate (Table III). The highest values of SJ were between the communities in $P$. cristatus and $P$. grisegena, and in P. nigricollis and T. ruficollis. The values of PS between component communities of $P$. cristatus, $P$. nigricollis and $P$. grisegena were moderate; in contrast, these values were considerably lower between $T$. ruficollis and each of the other three species (Table III).

\section{Dominant structure}

All the cestode component communities were characterised by a high number of satellite species and a low number of core species (Table I). This in P. grisegena had three, and those in P. nigricollis and T. ruficollis had only one core species. No core species was found in P. cristatus.

Four species ( $15 \%$ of the total species richness) were identified as core in at least one component community. Six species (22\%) were recognised as secondary. The satellite species contributed to the high richness of the component communities in P. cristatus, $P$. nigri- collis and T. ruficollis ( $89 \%, 80 \%$ and $77 \%$ of their species richness, respectively).

\section{Cestode INFRACOMMUNITIES}

The distribution of cestode species among the host samples suggested a random pattern in all grebe species (IDT, Chi-Square 8.118, 13.998, 2.692 and 5.1666; $\mathrm{dF}=11,20,3$ and 6 for $P$. cristatus, P. nigricollis, P. grisegena and T. ruficollis, respectively; $\mathrm{P}>0.05$ ). The cestode specimens, however, showed aggregated distributions for all four grebe species (variance/mean ratio 199.9, 530.9, 647.2 and 120.2 for P. cristatus, P. nigricollis, $P$. grisegena and T. ruficollis, respectively). The distribution of individuals was significantly different among the four sample sets (K-W H = 15.81, $\mathrm{p}=0.0012)$; however, the differences in the distribution of cestode species were not significant $(\mathrm{K}-\mathrm{W} \mathrm{H}=5.52, \mathrm{p}=0.1375$ ). The infracommunity diversity was low, as estimated by both diversity indices (Table II). The values of $d$ were high for all samples. No significant differences between the values of the diversity and dominance parameters were found when the four sample sets were compared. The qualitative and quantitative similarity among the infracommunities in each grebe species was low, rarely moderate (Table II). There were significant differences between the values of the similarity when comparisons were made among the four sample sets (K-W: SJ, $\mathrm{H}=19.9888, \mathrm{p}=0.0002$; PS, $\mathrm{H}=38.8772, \mathrm{p}=0.0000$ ). This was due to the significantly higher homogeneity of the infracommunities in $P$. nigricollis relative to those in P. cristatus (M-W: SJ, $\mathrm{U}=3702.5, \mathrm{p}=0.0000$; PS, $\mathrm{U}=2844.5, \mathrm{p}=0.0000)$ and in T. ruficollis $(\mathrm{M}-\mathrm{W}$ : SJ, $\mathrm{U}=1543.5, \mathrm{p}=0.0236 ; \mathrm{PS}, \mathrm{U}=1409.5, \mathrm{p}=0.0065$ ).

\section{PARTICIPATION OF GREBE SPECIALISTS}

IN THE CESTODE COMMUNITIES

Out of the 27 cestode species found, $21(78 \%)$ are grebe specialists (Table I). They represented 66.7-

\begin{tabular}{lllllllll}
\hline \multicolumn{1}{c}{ Jaccard similarity (SJ) } \\
\hline & AO-C & PG-C & PN-C & PA-C & PC-B & PN-B & PG-B & TR-B \\
\hline AO-C & & 0.533 & 0.450 & 0.615 & 0.188 & 0.250 & 0.231 & 0.150 \\
PG-C & 0.162 & & 0.391 & 0.500 & 0.158 & 0.167 & 0.188 & 0.083 \\
PN-C & 0.087 & 0.256 & & 0.500 & 0.077 & 0.133 & 0.087 \\
PA-C & 0.093 & 0.303 & 0.291 & & 0.176 & 0.182 & 0.214 \\
PC-B & 0.018 & 0.224 & 0.169 & 0.503 & & 0.103 \\
PN-B & 0.051 & 0.259 & 0.188 & 0.259 & 0.358 & & 0.143 \\
PG-B & 0.477 & 0.289 & 0.173 & 0.315 & 0.412 & 0.337 & 0.235 \\
TR-B & 0.013 & 0.031 & 0.044 & 0.031 & 0.026 & 0.101 & 0.048 \\
\hline
\end{tabular}

\section{Percent similarity (PS)}

Abbreviations: Grebes from Canada: AO-C, Aechmophorus occidentalis; PG-C, Podiceps grisegena; PN-C, P. nigricollis; PA-C, P. auritus. Grebes from the Bulgarian Black Sea coast: PC-B, P. cristatus; PN-B, P. nigricollis; PG-B, P. grisegena; TR-B, Tachybaptus ruficollis.

Table III. - Similarity values (SJ and PS) between cestode component communities in grebes from Bulgaria (present study) and Alberta (Stock \& Holmes, 1987). 
$100 \%$ of the species richness and $86.1-100 \%$ of the abundance in each component community. These species had also substantial role at the infracommunity level: the mean values of d' for each of the four infracommunity sample sets ranged between 0.4 and 1.0. The distributions of the species number and the abundance of grebe specialists, as well as d', were significantly different among the infracommunities in the four hosts (K-W: number of species, $\mathrm{H}=8.54, \mathrm{p}=0.0361$; number of individuals, $\mathrm{H}=15.84, \mathrm{p}=0.0012$; d', $\mathrm{H}=13.18, \mathrm{p}=0.0043$ ). The number of grebe specialist species in the infracommunities in P. cristatus was significantly lower compared to P. nigricollis $(\mathrm{M}-\mathrm{W}$ $\mathrm{U}=56.5, \mathrm{p}=0.0098)$ and $T$. ruficollis $(\mathrm{M}-\mathrm{W} \mathrm{U}=15.5$, $\mathrm{p}=0.0111$ ). Concerning the abundance of grebe specialists, it was significantly higher in the infracommunities in P. nigricollis compared to P. cristatus (M-W $\mathrm{U}=32.0, \mathrm{p}=0.0005)$ and $T$. ruficollis $(\mathrm{M}-\mathrm{W} \mathrm{U}=25.0$, $\mathrm{p}=0.0109)$. The communities in P. nigricollis had a significantly higher dominance of grebe specialists compared to P. cristatus ( $\mathrm{M}-\mathrm{W} \mathrm{U}=70.0, \mathrm{p}=0.0378$ ) and $P$. grisegena $(\mathrm{M}-\mathrm{W} \mathrm{U}=13.5, \mathrm{p}=0.0153)$. Grebe specialists exhibited also higher dominance in T. ruficollis compared to P. cristatus ( $\mathrm{M}-\mathrm{W} \mathrm{U}=17.5, \mathrm{p}=0.0182$ ) and $P$. grisegena $(\mathrm{M}-\mathrm{W} \mathrm{U}=3.5, \mathrm{p}=0.0212)$.

\section{DISCUSSION}

\section{COMPONENT COMMUNITIES}

Taxonomic structure

T The present results demonstrate a similar pattern of the cestode component community structure in the four grebe species. The main element of the richness and abundance is the group of grebe specialists (21 species) belonging to the Hymenolepididae (nine species of Confluaria, Dollfusilepis, Pararetinometra and Mackoja) and Amabiliidae (12 species of Tatria, Schistotaenia and Ryjikovilepis). In the case of T. ruficollis, they are the only component. In addition to the grebe specialists, the cestode communities in $P$. cristatus, $P$. grisegena and $P$. nigricollis include cestodes, which are generalists or specialists of other groups of aquatic birds. They have a minor role relative to the component community richness and abundance.

The group of the specialists of other aquatic birds includes four species. Three species of the hymenolepidid genera Fimbriarioides Fuhrmann, 1932 and Microsomacanthus Lopez-Neyra, 1942, recorded in P. grisegena and P. nigricollis, respectively, are parasites of anatid and larid birds (Spasskaya, 1966; Ryzhikov et al., 1985; Hoberg, 1996). The fourth species, Paricterotaenia porosa, is a common parasite of gulls (Laridae) (Ryzhikov et al., 1985; Hoberg, 1996). It has been found in $P$. nigricollis in Ukraine (Sergienko, 1972) and recorded in the same host by us. The most probable reasons for these records are the habitats and foods common to grebes and other aquatic birds. In particular, P. nigricollis associates with gulls and other aquatic birds outside the breeding season (B.B. Georgiev, personal observations).

The group of generalists contains two species. The record of Ligula intestinalis (Diphyllobothriidae) in $P$. cristatus is anticipated because this host is more piscivorous than the other Palaearctic grebes (Cramp \& Simmons, 1977; Simeonov et al., 1990). It should be mentioned that Ligula spp. exhibit low specificity to the definitive hosts (various piscivorous birds) and high specificity to the second intermediate host (fishes) (Dubinina, 1966). The second generalist is Tetrabothrius macrocephalus (Tetrabothriidae), a parasite of various marine birds (Temirova \& Skryabin, 1978). We have recorded it in the three larger grebe species, which tolerate more diverse habitats outside breeding season, i.e., coastal waters, saltwater lakes and lagoons (Cramp \& Simmons, 1977). However, it has not been found in T. ruficollis whose nesting and non-breeding habitats are almost entirely restricted to fresh waters (Cramp \& Simmons, 1977; Simeonov et al., 1990).

Stock \& Holmes (1987) recovered a total of 23 cestode species in four grebes (Aechmophorus occidentalis, $P$. grisegena, $P$. nigricollis and $P$. auritus) in Alberta. There are only six species occurring in both component communities in grebes from Alberta and Bulgaria. However, similarly to our results, the cestode component communities described by Stock \& Holmes (1987) are characterised by a high richness and abundance. In addition to the five families recorded by us, they also found a species of the family Dioecocestidae. In Alberta, 15 cestode species are grebe specialists. These were members of the families Hymenolepididae (nine out of 13 hymenolepidid species) and Amabiliidae (five species) which prevailed relative to the richness and abundance in all four component communities. Another grebe specialist, the dioecocestid Dioecocestus asper (Mehlis, 1831), occurred at low abundance in $P$. grisegena. The generalists were three species with a comparatively low abundance, two diphyllobothriids and one tetrabothriid (T. macrocephalus, syn. T. immerinus, see Temirova \& Skryabin, 1978). Two of these are the same as recorded in Bulgaria, plus Schistocephalus solidus (Muller, 1776). Specialists for other aquatic bird groups are five species (hymenolepidids and a dilepidid from anatids), all recorded in P. nigricollis only.

The comparison between the taxonomic structures of the cestode component communities in grebes from freshwater lakes in Alberta and from the Bulgarian Black Sea coast reveals several common features: 1) The 
main component of the cestode communities in Alberta and Bulgaria are the grebe specialists of the Hymenolepididae and Amabiliidae. 2) The range of the generalists includes almost the same taxa. 3) The range of the cestodes, which are specialists of other avian groups, includes mainly species parasitising anatids. In the context of the same comparison, the principal differences are as follows: 1) Though hymenolepidid and amabiliid grebe specialists are the major part of the component lists ( 21 species, or $77.8 \%$ for Bulgaria and 14 species, or $60.9 \%$ for Alberta), there are only four species in common for the two studies among them (Tatria biremis, Confluaria furcifera, C. podicipina and Pararetinometra lateralacantha). The considerable differences between the two species lists could be explained with their affiliation to different faunistic complexes (Palaearctic and Nearctic). 2) Some species recorded in both studies may have a different participation in the abundance of the component communities. The higher mean intensity of the marine species Tetrabothrius macrocephalus and the lower mean intensity of the freshwater species Ligula intestinalis in Bulgarian material in comparison to those in Canada could be explained by the coastal habitats where the Bulgarian samples were collected. L. intestinalis has a short life span in the final host (c. five days, see Dubinina, 1966) and, therefore, it could be expected to be a permanent and abundant component of the cestode communities in grebes in constant freshwater conditions only. The low abundance of Pararetinometra lateralacantha in Bulgaria could be explained by its apparent circumboreal distribution (Vasileva et al., 1996a); this species could be expected in Bulgaria in severe winters only when the northern populations of P. nigricollis migrate to the Black Sea (Simeonov et al., 1990). 3) The marine habitats of grebes examined in Bulgaria facilitate a restricted amount of transfer of cestodes from larids to $P$. nigricollis.

Similarity and diversity

The four grebe species examined in Bulgaria exhibit relatively low qualitative and quantitative similarity among the component communities (Table III). On the basis of their qualitative similarity, two groups of cestode component communities are outlined: 1) in smallsized grebe species, $P$. nigricollis and T. ruficollis, possessing 2 amabiliid and 5 hymenolepidid grebe specialists in common; 2) in large-sized grebe species, $P$. cristatus and $P$. grisegena, having 2 amabiliid and 1 hymenolepidid grebe specialists, and 1 generalist in common. This may be an indication for the partial dietary overlap of grebe species in each of both groups. The quantitative similarity analysis reveals that the component community in T. ruficollis is essentially different from those in the remaining three grebes studied. This may be interpreted as a reflection of both its ecological specialisation (e.g., the restriction to freshwater habitats and the lesser degree of dietary overlap with other grebes) and the evolutionary determined higher level of specificity of its cestodes (see the discussion on the host specificity below).

The qualitative similarity among cestode component communities in the four grebes from Alberta, calculated on the basis of the data of Stock \& Holmes (1987), is considerably higher as compared to our data (Table III). This is mainly due to the fact that 13 cestode species $(52.2 \%)$ are common for three or four host species in Alberta. In contrast, only four species (14.8\%) occur in three or four component cestode communities in grebes from Bulgaria. This difference suggests a lower degree of parasite exchange among the grebe species studied in Bulgaria than among the nesting populations in Alberta. It could be speculated that the main reason for this difference is the homogeneity of the freshwater nesting habitats in Alberta. The continued presence of various nesting grebe species on the same lakes may result into more efficient parasite cycling which increases cestode local populations. The trophic overlap in freshwater habitats, which is due to the ability of grebes for opportunistic feeding depending on the season and the available food resources (Cramp \& Simmons, 1977; Stock \& Holmes, 1987; Storer \& Nuechterlein, 1992), provides a common parasite pool for all the grebe species and can explain the higher extend of parasite exchange there.

In spite of the obvious differences of the qualitative similarity, the quantitative similarity calculated for the cestode component communities in Canadian grebes are almost within the same range compared to those in Bulgarian grebes (Table III). This indicates the similar patterns of the grebe species unequal contribution in maintaining the populations of certain cestode species. Stock \& Holmes (1987) considered that, though many parasites are shared among the grebe species, the major portion of each parasite population is concentrated in "the main host" species. The same is the case with the component communities studied in Bulgaria.

The present study and the survey of Stock \& Holmes (1987) provide comparable-sized samples of $P$. nigricollis. The component communities of this host from Alberta and Bulgaria contain only four species in common and exhibit very low qualitative and quantitative similarity (Table III). Applying the similarity as a criterion for the component community predictability (Holmes, 1990), this indicates the low predictability of the cestode component community in this host on a coarse geographical scale.

The comparison between the diversity measures based on summed data (HB, PIE' and d, see Table II) shows a considerably higher variability of the values for the 
component communities in Alberta and narrower ranges for those from Bulgaria. These results demonstrate a rather uneven distribution of cestode species among Canadian grebe populations.

\section{Dominant structure}

The dominant structure of the four cestode component communities in Bulgaria is characterised by a small number of core species (0-3). T. biremis is the only cestode, which is core in two grebe species (Table I). Each cestode component community is characterised by a distinct list of secondary species (Table I) or, in other words, each grebe species has a host-specific group of common cestode species. In contrast, the component communities in Canadian grebes exhibit a different dominant structure (Stock \& Holmes, 1987). It is characterised by a higher number of core species (2-6) (Table II). Four species attain core status in at least two component communities (out of 10 cestode species recognised as core). Since the prevalence criteria have been used for the identification of the dominant status of the cestode species, the observed difference can be explained by the more intense parasite cycling, respectively more abundant local populations, in the freshwater habitats.

\section{Host specificity}

The host specificity is usually defined as the extent to which a parasite taxon is restricted in the number of host species used at a given stage in the life cycle (e.g., Poulin, 1998). In relation to the specificity to their final host, the species recorded have to be regarded as generalists ("eurixene" parasites of Combes, 1995), grebe specialists ("stenoxene" and "oiioxene" parasites of Combes, 1995) and accidental parasites (specialists of other groups of aquatic birds occurring in grebes with low prevalence and abundance). The grebe specialists are the main element of the richness and abundance of the cestode communities both in Bulgaria (present results) and in Alberta (Stock \& Holmes, 1987). Nine out of the 10 cestode core species from Canada and all core species from Bulgaria are grebe specialists. Therefore, host specificity seems to be the main factor determining the structure of the cestode communities in grebes.

The extent of the host specificity revealed by Stock \& Holmes (1987) differs from that in our results. The only cestode species restricted to a single host (an "oiioxene" parasite) in Alberta is Dioecocestus asper. Almost all the other grebe specialists share two or more hosts; this low extent of specificity allows exchange among related host species (Stock \& Holmes, 1987). In our results there are four species restricted to a single host species ( $S$. rufi, T. octacantha, C. pseudofurcifera and $D$. hoploporus). Their narrow specificity is confirmed by data on their previous host records (Sulgostowska
\& Korpaczewska, 1969; Rees, 1973; Vasileva et al., 1998; 1999c). In addition to them, there is an intermediate group between the typical "stenoxene" and "oiioxene" parasites, which includes C. multistriata and $M$. podirufi. The bulk of their abundance is in T. ruficollis ("main or required host", a term proposed by Holmes et al., 1977); we found only single immature specimens of them in P. nigricollis. The previous records of these cestodes are also mainly from T. ruficollis (see Vasileva et al., 1996b, 1999b). These results indicate that the degree of interspecific cestode exchange is considerably lower in grebes at the Black Sea coast than in those from freshwater habitats in Canada.

\section{INFRACOMMUNITIES}

The infracommunities in the four host sample sets have a similar pattern of structure. All the infracommunities exhibit a low degree of diversity, a high dominance and a low similarity. There are no differences among the infracommunities in the grebe species examined relative to the distributions of species and the diversity parameters. Compared with our results, the species richness and abundance of the cestode infracommunities in breeding grebes in Canada (Stock \& Holmes, 1987) are higher (Table II). Probably, the almost constant conditions of breeding habitats enhance the higher cestode infestation. The decrease of the helminth infection parameters during migrations has been widely discussed by many authors (e.g., Dubinina, 1950; Dogel, 1962; Esch et al., 1990; Bush, 1990). The present results, obtained on the basis of host samples representing birds of migratory and overwintering populations, agree with the assumption that the same phenomenon may also have a major impact at the infracommunity level. However, since the infracommunities in grebes from Canada and Bulgaria are samples of different faunistic complexes (Nearctic and Palaearctic), the differences between them may also be determined by historical factors.

\section{CONCLUSIONS}

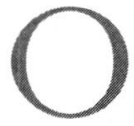
ur results and their comparison with the previous study on the helminth communities in grebes (Stock \& Holmes, 1987) exhibit several important differences and similarities.

The main distinctions between the results of the two investigations at the infracommunity level concern the higher species richness and abundance of the cestode infracommunities in breeding grebes in Canada. The most possible explanation is the almost constant conditions of breeding habitats enhancing the higher cestode transmission rates. 
At the component community level, there are several main differences. There is a significant difference between the two species lists, which could be explained by historical factors (their affiliation to different faunistic complexes). Other distinctions are the lower degree of the parasite exchange among the grebe species in Bulgaria and the different abundance of some common species (e.g., L. intestinalis and T. macrocephalus). These and the occurrence of specialists of larids in grebes from the Bulgarian coast can be explained mainly by habitat differences.

The following similar characters at the component community level are revealed: 1) the same pattern of the taxonomic structure at the generic and family levels which is characterised by the dominance of the grebe specialists of the families Hymenolepididae and Amabiliidae, almost the same species list of generalists, and the slight participation of hymenolepidid genera containing specialists of anatids; 2 ) close ranges of the quantitative similarity indicating a common pattern of an unequal contribution of the host species in the support of the cestode species populations; 3 ) the important role of the grebe specialists in cestode communities (i.e., the host specificity is the main factor for the determination of the community structure and the species richness in grebes). Evidently, these features of component communities of grebes do not depend on either historical (zoogeographical) factors or the different habitats utilised by grebes during the breeding season and during migration and overwintering.

\section{ACKNOWLEDGEMENTS}

W e are grateful to Dr A. K. Kostadinova for her numerous valuable suggestions at different stages of the work, to Dr R. A. Bray for reading the manuscript, and to Ms E. Herniou for translating the summary into French. In addition to the authors, the following colleagues participated in the field examinations of grebes in Bulgaria during a period of 10 years: T. Genov, A. Kostadinova, V. Biserkov, N. Chipev, G. Dimitrov, Z. Dimitrova, R. Hadjinikolova, V. Atanasova, R. Ivanova, B. Kalchishkova, S. Kotseva, Y. Atanasova, G. Nachev, P. Arsov and P. Peev.

\section{REFERENCES}

BAER J.G. Révision taxonomique et étude biologique des cestodes de la famille des Tetrabothriidae parasites d'oiseaux de haute mer et de mammifères marins. Mémoires de l'Université Neuchâtel, Série In-Quatro, 1954, 1, 4-122.

Baev P. \& Penev L. BIODIV. Program for calculating biological diversity parameters, similarity, niche overlap, and cluster analysis. Version 5.1. Exeter Software, New York, 1995,57 p.
Bush A.O. Helminth communities in avian hosts: determinants of pattern. In: Parasite Communities: Patterns and Processes. Esch G.W., Bush A.O. \& Aho J.M. (eds), Chapman \& Hall, London and New York, 1990, 197-232.

Bush A.O., Lafferty K.D., Lotz J.M. \& Shostak A.W. Parasitology meets ecology on its own terms: Margolis et al. revisited. Journal of Parasitology, 1997, 83, 575-583.

Combes C. Interactions durables: écologie et évolution du parasitisme. Masson, Paris, 1995, 524 p.

Cramp S. \& Simmons K.E.L. The Birds of the Western Palearctic. Volume 1. Oxford University Press, Oxford, 1977, 722 p.

Dubinina M.N. Tapeworms of birds overwintering in southern Tadjikistan. Parazitologicheskii Sbornik Akademii Nauk SSSR, 1950, 12, 351-381 (in Russian).

Dubinina M.N. The Ligulidae of the Fauna of the USSR. Nauka, Moscow, 1966, 261 p. (in Russian).

Dogel V.A. General Parasitology. Izdatel'stvo LGU, Leningrad, 1962, 464 p. (in Russian).

Esch G.W., Shostak A.W., Marcogliese D.J. \& Goater T.M. Patterns and processes in helminth parasite communities: an overview. In: Parasite communities: patterns and processes. Esch G.W., Bush A.O. \& Aho J.M. (eds), Chapman \& Hall, London and New York, 1990, 1-19.

Galkin A.K. On the cestode fauna of grebes (Podiceps) of the Kurish Spit. Trudy Zoologicheskogo Instituta AN SSSR, 1986, 155, 119-127 (in Russian).

GULYAEV V.D. On the morphology and taxonomy of Tatria (s. 1.) (Cestoda, Schistotaeniidae) of grebes in the West Siberia and Transurals. In: Novye i Maloizvestnye Vidy Fauny Sibiri, 1990, 21, 4-19 (in Russian).

GulyaEv V.D. Morphological criteria of the genus Tatria Kowalewski, 1904 (Cestoda: Schistotaeniidae). Sibirskiy Biologicheskiy Zhurnal, 1992, 4, 68-75 (in Russian).

Hoberg E.P. Faunal diversity among avian parasite assemblages: the interaction of history, ecology, and biogeography in marine systems. Bulletin of Scandinavian Society of Parasitology, 1996, 6 (2), 65-89.

Holmes J.C. Helminth communities in marine fishes. In: Parasite communities: patterns and processes. Esch G.W., Bush A.O. \& Aho J.M. (eds), Chapman \& Hall, London and New York, 1990, 101-130.

Holmes J.C., HobBs R.D. \& LeONG T.S. Populations in perspective: community organization and the regulation of parasite populations. In: Regulation of parasite populations. Esch G.W. (Ed), Academic Press, New York, 1977, 209-245.

Kostadinova A. Trematodes and trematode communities in fish-eating birds from the Bulgarian Black Sea Coast. Ph.D. Thesis, Institute of Parasitology, Bulgarian Academy of Sciences, Sofia, 1993, 220 p.

Krebs C.J. Ecological Methodology. Harper Collins Publishers, New York, 1989, 654 p.

MagurRan A.E. Ecological diversity and its measurement. Princeton University Press, New Jersey, 1988, 125 p.

Poulin R. Evolutionary ecology of parasites. Chapman \& Hall, London, 1998, 212 p. 
ReEs G. Cysticercoids of three species of Tatria (Cyclophyllidea: Amabiliidae) including T. octacantha sp. nov. from the haemocoele of the damsel-fly nymphs Pyrrbosoma nymphula Sulz and Enallagma cyathigerum Charp. Parasitology, 1973, 66, 423-446.

RYzhIKOV K.M. \& TOlKaCheva L.M. Principles of cestodology. Volume 10. Acoleata-cestodes of birds. Nauka, Moscow, 1981, 215 p. (in Russian).

Ryzhikov K.M., Rysavy B., Khokhlova I.G., Tolkacheva L.M. \& KorNYUSHIN V.V. Helminths of fish-eating birds of the palaearctic region. Volume II. Cestoda and Acanthocephales. Academia, Prague, 1985, 411 p.

Simeonov S.D., Michev T.M. \& Nankinov D.N. Fauna of Bulgaria. Volume 20. Aves, Part I. Izdatelstvo na Balgarskata Akademiya na Naukite, Sofia, 1990, 350 p. (in Bulgarian).

SERGIENKo M.I. Parasitic worms of grebes (Colymbi) of upper Dnester basin. Parazity, Parazitocenozy i Puty ich Likvidacii, 1972, 1, 131-135 (in Russian).

SOKAL R.R. \& Rohlf F.J. Biometry. The principles and practice of statistics in biological research $\left(2^{\text {nd }}\right.$ ed.). W.H. Freeman \& Co., New York, 1981, 859 p.

SPASSKAYA L.P. Cestodes of birds of the USSR. Hymenolepididae. Nauka, Moscow, 1966, 698 p. (in Russian).

Stock T.M. \& Holmes J.C. Host specificity and exchange of intestinal helminths among four species of grebes (Podicipedidae). Canadian Journal of Zoology, 1987, 65, 669676.

STOск T.M. \& Holmes J.C. Functional relationships and microhabitat distributions of enteric helminths of grebes (Podicipedidae): the evidence for interactive communities. Journal of Parasitology, 1988, 74, 214-227.

'Storer R.W. \& Nuechterlein G.L. Western and Clark's Grebe. In: The birds of North America, No 26. Poole A., Stettenheim P. \& Gill F. (eds), The Academy of Natural Sciences, Philadelphia; The American Ornithologists' Union, Washington, 1992, 24 p.

SulgostowsKa T. \& KORPACZEWSKA W. Schistotaenia rufi sp. n. (Cestoda: Amabiliidae). Acta Parasitologica Polonica, 1969, 15, 132-138

Temirova S.I. \& Skryabin A.S. Suborder Tetrabothriata (Ariola, 1899) Skryabin, 1940. In: Principles of cestodology. Volume 9. Tetrabothriata and Mesocestoidata, cestodes of birds and mammals. Izdatel'stvo Akademii Nauk SSSR, Moscow, 1978, 7-117 (in Russian).

Vasileva G.P., Georgiev B.B. \& Genov T. Pararetinometra lateralacantha Stock and Holmes, 1981 (Cestoda, Hymenolepididae): the first record in the Palaearctic Region and comments on its morphology and taxonomy. Canadian Journal of Zoology, 1996a, 74, 110-117.

VAsileva G.P., Georgiev B.B. \& Genov T. Redescription and new records of Mackoja podirufi (Macko, 1962), with an amended diagnosis of Mackoja Kornyushin, 1983. Systematic Parasitology, 1996b, 34, 171-177.

VAsileva G.P., Georgiev B.B. \& Genov T. Redescription of Hymenolepis hoploporus Dollfus, 1951, with the erection of the new genus Dollfusilepis (Cestoda, Hymenolepididae). Revue Suisse de Zoologie, 1998, 105, 319-329.
Vasileva G.P., Georgiev B.B. \& Genov T. Palaearctic species of the genus Confluaria Ablasov (Cestoda, Hymenolepididae): redescription and synonymy of $C$. capillaris (Rudolphi). Systematic Parasitology, 1999a, 43, 49-57.

Vasileva G.P., Georgiev B.B. \& Genov T. Palaearctic species of the genus Confluaria Ablasov (Cestoda, Hymenolepididae): redescriptions of C. multistriata (Rudolphi, 1810) and C. japonica (Yamaguti, 1935), and a description of Confluaria sp. Systematic Parasitology, 1999b, in press.

Vasileva G.P., Georgiev B.B. \& Genov T. Palaearctic species of the genus Confluaria Ablasov (Cestoda, Hymenolepididae): redescriptions of C. podicipina (Szymanski, 1905) and C. furcifera (Krabbe, 1869), description of C. pseudofurcifera n. sp., a key and final comments. Systematic Parasitology, 1999c, in press.

Reçu le 9 mars 1999 Accepté le 25 juin 1999 